\title{
Determination of Formaldehyde Content by High Performance Liquid Chromatography in Some Fruits of Local Market in Dhaka City, Bangladesh
}

\author{
Murira Khandakar Sadia \\ Department of Food Technology and Nutritional Science, Mawlana Bhashani Science and Technology \\ University, Tangail-1902, Bangladesh
}

Md Shabudden Ahamed*

Department of Food and Nutritional Science, Rajshahi Institute of Biosciences, University of Rajshahi, Rajshahi6212, Bangladesh

Luthfunnesa Bari

Department of Food Technology and Nutritional Science, Mawlana Bhashani Science and Technology University, Tangail-1902, Bangladesh

\begin{abstract}
The present study was conducted to determine the formaldehyde content in three mostly consumed fruits (mango, apple and grape) in Bangladesh. A total of 81 samples were collected from three different local markets of Dhaka city (Mohammadpur Bazaar, Mohakhali Bazaar and Gulistan Bazaar). High Performance Liquid Chromatography (HPLC) with c-18 column and UV detector at $355 \mathrm{~nm}$ were used to determine the formaldehyde content. The mobile phase was $50 \%$ acetonitrile with a flow rate $1 \mathrm{ml} / \mathrm{min}$. The concentration of formaldehyde in mango was from $1.86 \mathrm{mg} / 100 \mathrm{~g}$ to $11.65 \mathrm{mg} / 100 \mathrm{~g}$ in Mohammadpur Bazaar, $1.45 \mathrm{mg} / 100 \mathrm{~g}$ to $10.69 \mathrm{mg} / 100 \mathrm{~g}$ in Mohakhali Bazaar and $1.69 \mathrm{mg} / 100 \mathrm{~g}$ to $4.41 \mathrm{mg} / 100 \mathrm{~g}$ in Gulistan Bazaar. It was found that $2.28 \mathrm{mg} / 100 \mathrm{~g}$ to $7.30 \mathrm{mg} / 100 \mathrm{~g}$, $2.33 \mathrm{mg} / 100 \mathrm{~g}$ to $11.77 \mathrm{mg} / 100 \mathrm{~g} \& 1.42 \mathrm{mg} / 100 \mathrm{~g}$ to $5.39 \mathrm{mg} / 100 \mathrm{~g}$ formaldehyde contained in apple for Mohammadpur, Mohakhali, Gulistan Bazaar respectively. Among the selected sample, the content of formaldehyde in grape was lower than mango and apple. The amount of formaldehyde in grape was $0.93 \mathrm{mg} / 100 \mathrm{~g}$ to $4.63 \mathrm{mg} / 100 \mathrm{~g}, 1.92 \mathrm{mg} / 100 \mathrm{~g}$ to $3.84 \mathrm{mg} / 100 \mathrm{~g} \& 1.42 \mathrm{mg} / 100 \mathrm{~g}$ to $4.92 \mathrm{mg} / 100 \mathrm{~g}$ for Mohammadpur, Mohakhali, Gulisthan market. The highest formaldehyde concentrations $(11.77 \mathrm{mg} / 100 \mathrm{~g})$ were detected in apple fruit, exceeding the naturally found permissible limit of 0.63 to $2.23 \mathrm{mg} / 100 \mathrm{gm}$; the second highest formaldehyde concentration $(11.65 \mathrm{mg} / 100 \mathrm{~g}$ ) were found in mango, exceeding the permissible limit of 0.1 to $6 \mathrm{mg} / 100 \mathrm{gm}$; while the grape also contains high level of formaldehyde concentration $(4.92 \mathrm{mg} / 100 \mathrm{~g})$ exceeding the permissible limits $2.24 \mathrm{mg} / 100 \mathrm{gm}$. It was surprisingly found that the $22.22 \%$ of mango, $85.19 \%$ of apple and $66.67 \%$ of grape contained formalin above the permissible limit.
\end{abstract}

Keywords: Fruits, Formaldehyde, HPLC, Food Safety

DOI: $10.7176 / \mathrm{FSQM} / 96-06$

Publication date: April $30^{\text {th }} 2020$

\section{Introduction}

The ridiculous use of formalin in fruits and vegetables is a growing concern globally. It is suspected that fruits and vegetables in the market may be treated with formalin to extend their shelf life. Almost all of the people of Bangladesh are largely depend on fruits and vegetables to meet the demand of vitamins and minerals. Dhaka city is the mostly densely populated. To meet the demand of fruits of densely populated metropolitan city such as Dhaka city, traders need to collect fruits from rural area. Moreover to earn more profits local farmers supply fruits from rural to urban. In both cases they need to preserve the fruits for long time till to sell. Fresh fruits are essential components of a healthy and nutritious diet. They are rich in vitamins, dietary fiber and minerals whose regular consumption has been associated with reduced risks of chronic diseases such as diabetes, atherosclerosis, stroke and certain cancers (Adedotun A.et al., 2015). Bangladesh produces a large amount of fruits every year, 28th in total fruit production worldwide. Fruits are not a domestic food, but also a commercial crop now days. But the postharvest technology, cold storage facilities and transport facilities in inadequate. Consumption of formalin treated food stuffs may cause uncontrolled cell growth or cancer in any part of the body like stomach, lung and respiratory system (Rose et al, 2002). Besides, inhalation of formaldehyde causes respiratory system cancer (Marsh et al, 2007).

Formaldehyde is converted to formic acid into body leading to a rise in blood acidity, slow breathing, hypothermia and coma or death. People who have ingested formaldehyde require immediate medical attention. In the body, formaldehyde can cause proteins to irreversibly bind to DNA. Formaldehyde is listed as a probable human carcinogen. Formaldehyde is classified by the U.S. EPA as a probable human carcinogen, and as 
carcinogenic by the World Health Organization (Smedjeet al., 2011). Toxic administration of formalin produces inflammatory lesions in the oropharynx, soft palate, pharynx, epiglottis, esophagus and stomach. Later it may result in loss of memory, seizures, altered behavior, and consciousness which finally ends up with coma or death of the patient. (Wantke F et al., 2000). The ingestion of formaldehyde over a prolonged period can develop respiratory, digestive, cardiac, nephrological and neurological problems, along with cancer. (Kamruzzaman $\mathrm{M}$ et al., 2016a) (Kamruzzaman M et al., 2016b) (Hossain MM. 2011) (Hossain MS et al., 2008)

Formaldehyde is used as a food preservative illegally since it can prolong the shelf-life of a food by protecting against deterioration caused by microorganisms. Some dishonest traders are using formalin widely in preservation of food items, like fish, tofu, noodles, vermicelli, milk, meat, salted dried fish and also fruits or vegetables. It is also used to increase the freshness and attractiveness of foods. Formaldehyde is present in many animal and plant species as a product of their normal metabolism. It can be found naturally in food including fruits, vegetables, meats, marine fish and crustacean with the levels up to 300 to $400 \mathrm{mg} / \mathrm{kg}$. Recently great attention has been paid to the presence of formalin in foodstuffs in our country. However, presence of formalin in foodstuffs has been more a rumor than a scientific proven fact. Up to date only qualitative methods have been used to detect the presence of formaldehyde in foods. Due to the ubiquitous nature of formaldehyde a positive response on qualitative test is expected. Thus, the importance of developing an accurate analytical method able to distinguish between incurred and added levels of formaldehyde. To determine the accurate level of formaldehyde in fruits were measured by HPLC method. Other techniques, such as LC and GC, have been proven to be more selective and accurate in determining formaldehyde in water mushrooms, milk (Kaminski, Atwal, \& Mahadevan, 1993), fish (Jianrong et al., 2007; Tai-Sheng et al., 2013) and shrimps.

Now a day the rampant addition of formalin to perishable food to increase their shelf life is a common feature. Fruits are one of the perishable foods which shelf life are few days from harvesting. As a result the fruits traders used formalin to increase the shelf life of the products. Apple \& Grape are the most common fruit of local market of Dhaka and available around the year everywhere in Bangladesh whereas Mangoes are seasonal fruits which are abundant in summer season. In recent times there is an increase in demand on food safety research global food production, processing and preparation in order to ensure a safer global food. The chemical contamination presence in food can cause the major sources of carcinogenic disease. Generally after buying fruits we eat fruits in fresh condition. However cooking of some food such as fish, meat and vegetables can lower the amount of formalin present in them but eating fruits it is necessary to know the amount of formalin as they remain in safe level.

\section{Materials and Methods}

Three categories of fruits Mango, Apple \& Grape were collected from different market of Dhaka city. The selected markets were Mohammadpur Town Hall Bazaar, Mohakhali Kacha Bazaar and Gulistan Bazaar. This was a lab based experimental study and carried out by High Performance Liquid Chromatography (HPLC) technique. The study was conducted in research laboratory in Dept. of Food Technology and Nutritional Science (FTNS), Mawlana Bhashani Science and Technology University (MBSTU), Santosh, Tangail-1902, Bangladesh. A Total of 81 fruits samples were collected from 3 shops of 3 different bazaars for this experiment. Total sample divided in three categories, 27 samples of mango, 27 samples of grapes and 27 samples of apple. From each shop 3 samples of mango, apple \& grape were taken.

\section{Methods}

Chemicals

Formaldehyde soluble in water $37 \%$ CRM) was brought from Merck, Germany. HPLC grade 2,4dinitrophenylehydrazene $\left(\mathrm{C}_{6} \mathrm{H}_{6} \mathrm{~N}_{4} \mathrm{O}_{4}\right)$ was brought from DEJUNG CHEMICALS \& METAlSCo., LTD, Korea. Acetonitrile, HPLC grade was brought from DEJUNG CHEMICALS \& METAIS Co., LTD, Korea. Deionized water used for chromatography processing was procured from a Labconco WATER PRO PS purifier. Phosphoric acid (H2PO4), 85\% solution was brought from Merck, Germany.

\section{Reagent preparation}

2, 4, DNPH (dinitrophenylhydrazene): DNPH was recentralized prior to use. Recentralization was performed by dissolving and excess of DNPH in $10 \mathrm{ml}$ hot acetonitrile analytical grade to form a saturated solution. After completion of dissolution, the solution was cooled to room temperature, capped in a brown bottle and stored overnight at $4 \mathrm{OC}$ for further crystallization. The crystals were collected by vacuum filtration. $150 \mathrm{mg}$ of DNPH crystal were accurately weighted \pm 0.00 and dissolved in $49.5 \mathrm{ml}$ acetonitrile and mixed with $0.5 \mathrm{ml}$ of H3PO4 $(85 \%)$.

\section{Standard preparation}

Formaldehyde standard was prepared from certified reference material's stock solution. First stock solution was prepared by dissolving $1 \mathrm{ml}$ of CRM standard solution into $99 \mathrm{ml} \mathrm{H} 2 \mathrm{O}$ which concentration was $4033 \mu \mathrm{g} / \mathrm{ml}$. 
Second stock solutions or working stock solution of $403.3 \mu \mathrm{g} / \mathrm{ml}$ prepared by dissolving $1 \mathrm{ml}$ of first stock solution into $10 \mathrm{ml} \mathrm{H} 2 \mathrm{O}$. Standard solutions of formalin were prepared by these following concentrations $0,10,20,30,40$, 50 and $60 \mu \mathrm{g} / \mathrm{ml}$

\section{Sample preparation}

a) $7 \mathrm{ml}$ analytical grade acetonitrile mixed with $7 \mathrm{gm}$ fruit sample and vortex for 2 to $3 \mathrm{~min}$

b) Then the sample was ultrasonicated for $30 \mathrm{~min}$ at room temperature $(27 \mathrm{oc})$. After sonication the mixed sample was centrifuged ( $5 \mathrm{~min}, 600 \mathrm{rpm}$, at $21 \mathrm{oc}$ ) to separate the liquid part from solid portion.

c) The liquid portion was filtered through whatman filter paper to get clear solution. From the filtered clear solution approximately $3 \mathrm{ml}$ were taken

d) $1.5 \mathrm{ml}$ working DNPH solution was added with clear solution and vortex well. After that the mixed sample was filter by syringe filter to get supernatant solution and $1 \mathrm{ml}$ was taken in apendrop.

e) The collected supernatant micro centrifuged at $600 \mathrm{rpm}$ for $5 \mathrm{~min}$ at $270 \mathrm{c}$. Again the solution was syringe filtered to get the final supernatant solution.

Analysis of formaldehyde

HPLC method was applied to determine the content of formaldehyde in this experiment. This formaldehyde was eluted from the Luna $5 \mu \mathrm{C} 18$ (2) $100 \mathrm{~A}$ column $(250 \times 4.6)$ with binary solvent system with $50 \%$ acetonitrile. The flow rate was $1 \mathrm{~m} / \mathrm{min} \%$ the eluent was monitored by UV detector at $355 \mathrm{~nm}$. The retention time of formaldehyde standard was $11.36 \pm$ minutes and approximate time was set $15 \mathrm{~min}$ (Fig 1A). Each of the tests was carried out at two replicates.

\section{Results and Discussion}

HPLC method was applied to determine the content of formaldehyde in this experiment. This formaldehyde was eluted from the Luna $5 \mu \mathrm{C} 18$ (2) $100 \mathrm{~A}$ column $(250 \times 4.6)$ with binary solvent system with $50 \%$ acetonitrile. The flow rate was $1 \mathrm{~m} / \mathrm{min} \%$ the eluent was monitored by UV detector at $355 \mathrm{~nm}$. The retention time of formaldehyde standard was $11.36 \pm$ minutes and approximate time was set $15 \mathrm{~min}$. Each of the tests was carried out at two replicates.

Table 1: Concentration of formaldehyde in control of sample of mango, apple and grape

\begin{tabular}{|c|c|c|c|}
\hline \multirow{2}{*}{ Sample } & \multicolumn{2}{|c|}{ Concentration of formaldehyde(mg/100gm) } & \multirow{2}{*}{ Mean \pm SD } \\
\cline { 2 - 3 } & Replicate1 & Replicate2 & $1.75 \pm 0.02$ \\
\hline Mango & 1.73 & 1.76 & $1.42 \pm 0.20$ \\
\hline Apple & 1.28 & 1.56 & $1.57 \pm 0.03$ \\
\hline Grape & 1.28 & 1.56 & . \\
\hline
\end{tabular}

Table 1 showed the level of formaldehyde in control sample of mango, apple and grape According to the World Health Organization (WHO), in apple formalin contain 6.3 to $22.3 \mathrm{mg} / \mathrm{kg}$, in grape $22.4 \mathrm{mg} / \mathrm{kg}$ and in mango 1 to $60 \mathrm{ppm}$ naturally. The control sample of mango, apple and grape collected from agricultural farm. The sample's shelf life was observed in lab. The table indicated that the control had satisfactory formaldehyde level which is within the permitted limit.

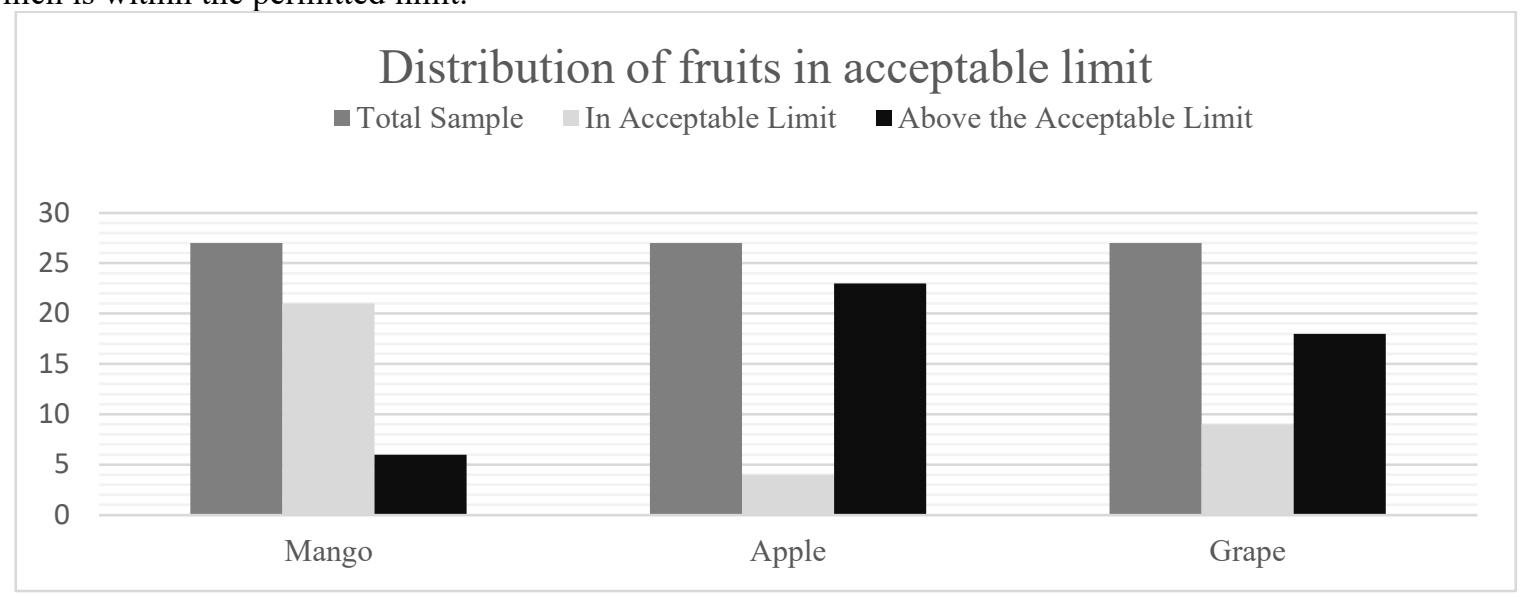

Figure 1: Distribution of fruits in formaldehyde content in acceptable limit

A total of 27 sample of each fruit as mango, apple and grape were analyzed collected from three different shops each of the local market of Mohammadpur, Mohakhali \& Gulistan. The HPLC chromatogram of formaldehyde content in fruits had the peak identity with formaldehyde standard chromatograms. 21 sample of mango, 4 sample of apple and 9 sample grape were detected as safe whereas 6 sample of mango, 23 sample of 
apple and 18 sample of grape are found as above the acceptable limit.

Table 2: Concentration of formaldehyde of mango in three different markets

\begin{tabular}{|c|c|c|c|c|c|}
\hline Name of Market & No. of Shop & No. of Sample & Replicate 1 & Replicate 2 & Mean \pm SD \\
\hline \multirow{9}{*}{$\begin{array}{l}\text { Mohammadpur } \\
\text { Bazaar }\end{array}$} & \multirow{3}{*}{ Shop no 1} & Sample1 & 2.72 & 2.75 & $2.73 \pm 0.02$ \\
\hline & & Sample2 & 5.63 & 5.60 & $5.62 \pm 0.02$ \\
\hline & & Sample3 & 1.79 & 1.93 & $1.86 \pm 0.10$ \\
\hline & \multirow[t]{3}{*}{ Shop no 2} & Sample1 & 4.09 & 4.10 & $4.10 \pm 0.01$ \\
\hline & & Sample2 & 5.50 & 5.54 & $5.52 \pm 0.03$ \\
\hline & & Sample3 & 5.09 & 5.11 & $5.10 \pm 0.01$ \\
\hline & \multirow[t]{3}{*}{ Shop no 3} & Sample1 & 11.61 & 11.68 & $11.65 \pm 0.05$ \\
\hline & & Sample2 & 10.27 & 10.36 & $10.32 \pm 0.06$ \\
\hline & & Sample3 & 6.27 & 6.33 & $6.30 \pm 0.04$ \\
\hline \multirow{9}{*}{$\begin{array}{l}\text { Mohakhali } \\
\text { Bazaar }\end{array}$} & \multirow[t]{3}{*}{ Shop no 1} & Sample1 & 3.32 & 3.33 & $3.32 \pm 0.00$ \\
\hline & & Sample2 & 5.99 & 6.12 & $6.05 \pm 0.09$ \\
\hline & & Sample3 & 10.74 & 10.61 & $10.69 \pm 0.12$ \\
\hline & \multirow[t]{3}{*}{ Shop no 2} & Sample1 & 5.79 & 5.71 & $5.75 \pm 0.06$ \\
\hline & & Sample2 & 3.69 & 3.65 & $3.67 \pm 0.03$ \\
\hline & & Sample3 & 1.45 & 1.45 & $1.45 \pm 0.00$ \\
\hline & \multirow[t]{3}{*}{ Shop no 3} & Sample1 & 3.66 & 3.61 & $3.64 \pm 0.04$ \\
\hline & & Sample2 & 7.51 & 7.60 & $7.55 \pm 0.07$ \\
\hline & & Sample3 & 2.10 & 2.07 & $2.09 \pm 0.02$ \\
\hline \multirow[t]{9}{*}{ Gulistan Bazaar } & \multirow[t]{3}{*}{ Shop no 1} & Sample1 & 4.42 & 4.41 & $4.41 \pm 0.00$ \\
\hline & & Sample2 & 2.93 & 3.06 & $3.00 \pm 0.09$ \\
\hline & & Sample3 & 3.12 & 3.13 & $3.12 \pm 0.01$ \\
\hline & \multirow[t]{3}{*}{ Shop no 2} & Sample1 & 3.17 & 3.23 & $3.20 \pm 0.04$ \\
\hline & & Sample2 & 3.23 & 3.12 & $3.17 \pm 0.08$ \\
\hline & & Sample3 & 1.75 & 1.63 & $1.69 \pm 0.09$ \\
\hline & \multirow[t]{3}{*}{ Shop no 3} & Sample1 & 3.60 & 3.64 & $3.62 \pm 0.03$ \\
\hline & & Sample2 & 2.80 & 3.13 & $2.97 \pm 0.24$ \\
\hline & & Sample3 & 2.85 & 2.78 & $2.82 \pm 0.04$ \\
\hline
\end{tabular}

Table 2 showed the range of formaldehyde content in mango collected from three different shops of three local markers. The formaldehyde content of mango found is $11.65 \pm 0.05$ as maximum in Mohammadpur bazaar whereas the minimum content of formalin found as 1.69 \pm 0.09 in Gulistan Bazaar. 6 samples of mango are found as above the acceptable limit for human consumption. 
Table 3: Concentration of formaldehyde of Apple in three different markets

\begin{tabular}{|c|c|c|c|c|c|}
\hline Name of Market & No. of Shop & No. of Sample & Replicate 1 & Replicate 2 & Mean \pm SD \\
\hline \multirow{9}{*}{$\begin{array}{l}\text { Mohammadpur } \\
\text { Bazaar }\end{array}$} & \multirow[t]{3}{*}{ Shop no 1} & Sample1 & 4.38 & 4.40 & $4.39 \pm 0.01$ \\
\hline & & Sample2 & 3.26 & 3.29 & $3.28 \pm 0.02$ \\
\hline & & Sample3 & 5.38 & 5.42 & $5.40 \pm 0.03$ \\
\hline & \multirow[t]{3}{*}{ Shop no 2} & Sample1 & 3.57 & 3.59 & $3.58 \pm 0.01$ \\
\hline & & Sample2 & 7.24 & 7.36 & $7.30 \pm 0.09$ \\
\hline & & Sample3 & 3.94 & 4.03 & $3.98 \pm 0.06$ \\
\hline & \multirow[t]{3}{*}{ Shop no 3} & Sample1 & 2.83 & 2.86 & $2.84 \pm 0.02$ \\
\hline & & Sample2 & 4.39 & 4.54 & $4.46 \pm 0.10$ \\
\hline & & Sample3 & 2.33 & 2.24 & $2.28 \pm 0.07$ \\
\hline \multirow{9}{*}{$\begin{array}{l}\text { Mohakhali } \\
\text { Bazaar }\end{array}$} & \multirow[t]{3}{*}{ Shop no 1} & Sample1 & 4.26 & 4.40 & $4.33 \pm 0.10$ \\
\hline & & Sample2 & 11.16 & 12.38 & $11.77 \pm 0.86$ \\
\hline & & Sample3 & 5.61 & 5.58 & $5.59 \pm 0.02$ \\
\hline & \multirow[t]{3}{*}{ Shop no 2} & Sample1 & 3.11 & 3.09 & $3.10 \pm 0.01$ \\
\hline & & Sample2 & 3.37 & 3.60 & $3.48 \pm 0.16$ \\
\hline & & Sample3 & 2.99 & 2.89 & $2.94 \pm 0.07$ \\
\hline & \multirow[t]{3}{*}{ Shop no 3} & Sample1 & 2.33 & 2.32 & $2.33 \pm 0.00$ \\
\hline & & Sample2 & 3.68 & 3.88 & $3.78 \pm 0.14$ \\
\hline & & Sample3 & 3.06 & 1.83 & $2.44 \pm 0.87$ \\
\hline \multirow[t]{9}{*}{ Gulistan Bazaar } & \multirow[t]{3}{*}{ Shop no 1} & Sample1 & 3.24 & 3.30 & $3.27 \pm 0.10$ \\
\hline & & Sample2 & 3.82 & 4.06 & $3.94 \pm 0.86$ \\
\hline & & Sample3 & 3.38 & 3.40 & $3.59 \pm 0.02$ \\
\hline & \multirow[t]{3}{*}{ Shop no 2} & Sample1 & 5.35 & 5.44 & $5.39 \pm 0.01$ \\
\hline & & Sample2 & 2.33 & 2.66 & $2.49 \pm 0.16$ \\
\hline & & Sample3 & 4.07 & 4.14 & $4.10 \pm 0.07$ \\
\hline & \multirow[t]{3}{*}{ Shop no 3} & Sample1 & 1.36 & 1.44 & $1.42 \pm 0.06$ \\
\hline & & Sample2 & 4.10 & 4.21 & $4.15 \pm 0.14$ \\
\hline & & Sample3 & 3.32 & 3.80 & $3.56 \pm 0.87$ \\
\hline
\end{tabular}

Table 3 showed the range of formaldehyde content in apple collected from three different shops of three local markers. The formaldehyde content of apple found is $11.77 \pm 0.86$ as maximum in Mohammadpur bazaar whereas the minimum content of formalin found as $1.42 \pm 0.06$ in Gulistan Bazaar. 23 samples of apple are found as above the acceptable limit for human consumption. 
Table 4: Concentration of formaldehyde of grape in three different markets

\begin{tabular}{|c|c|c|c|c|c|}
\hline Name of Market & No. of Shop & No. of Sample & Replicate 1 & Replicate 2 & Mean \pm SD \\
\hline \multirow{9}{*}{$\begin{array}{l}\text { Mohammadpur } \\
\text { Bazaar }\end{array}$} & \multirow[t]{3}{*}{ Shop no 1} & Sample1 & 4.39 & 4.36 & $4.37 \pm 0.02$ \\
\hline & & Sample2 & 2.76 & 2.79 & $2.77 \pm 0.02$ \\
\hline & & Sample3 & 1.67 & 1.73 & $1.70 \pm 0.04$ \\
\hline & \multirow[t]{3}{*}{ Shop no 2} & Sample1 & 4.44 & 4.85 & $4.64 \pm 0.29$ \\
\hline & & Sample2 & 0.91 & 0.95 & $0.93 \pm 0.03$ \\
\hline & & Sample3 & 2.51 & 2.53 & $2.52 \pm 0.01$ \\
\hline & \multirow[t]{3}{*}{ Shop no 3} & Sample1 & 2.84 & 2.92 & $2.88 \pm 0.06$ \\
\hline & & Sample2 & 1.41 & 1.48 & $1.45 \pm 0.05$ \\
\hline & & Sample3 & 2.67 & 2.79 & $2.73 \pm 0.08$ \\
\hline \multirow{9}{*}{$\begin{array}{l}\text { Mohakhali } \\
\text { Bazaar }\end{array}$} & \multirow[t]{3}{*}{ Shop no 1} & Sample1 & 2.23 & 2.18 & $2.20 \pm 0.10$ \\
\hline & & Sample2 & 3.19 & 3.41 & $3.3 \pm 0.86$ \\
\hline & & Sample3 & 2.42 & 2.47 & $2.44 \pm 0.02$ \\
\hline & \multirow[t]{3}{*}{ Shop no 2} & Sample1 & 3.14 & 3.55 & $3.35 \pm 0.01$ \\
\hline & & Sample2 & 2.16 & 2.46 & $2.31 \pm 0.16$ \\
\hline & & Sample3 & 3.79 & 3.81 & $3.84 \pm 0.07$ \\
\hline & \multirow[t]{3}{*}{ Shop no 3} & Sample1 & 2.15 & 2.20 & $2.33 \pm 0.04$ \\
\hline & & Sample2 & 2.75 & 2.71 & $2.75 \pm 0.14$ \\
\hline & & Sample3 & 1.84 & 2.00 & $1.92 \pm 0.87$ \\
\hline \multirow[t]{9}{*}{ Gulisthan Bazaar } & \multirow[t]{3}{*}{ Shop no 1} & Sample1 & 3.12 & 3.11 & $3.11 \pm 0.01$ \\
\hline & & Sample2 & 4.58 & 5.14 & $4.86 \pm 0.40$ \\
\hline & & Sample3 & 4.76 & 5.08 & $4.92 \pm 0.23$ \\
\hline & \multirow[t]{3}{*}{ Shop no 2} & Sample1 & 1.55 & 1.81 & $1.68 \pm 0.18$ \\
\hline & & Sample2 & 1.46 & 1.47 & $1.47 \pm 0.01$ \\
\hline & & Sample3 & 1.40 & 1.42 & $1.41 \pm 0.01$ \\
\hline & \multirow[t]{3}{*}{ Shop no 3} & Sample1 & 2.27 & 2.31 & $2.29 \pm 0.02$ \\
\hline & & Sample2 & 1.78 & 1.91 & $1.84 \pm 0.09$ \\
\hline & & Sample3 & 2.59 & 3.01 & $2.80 \pm 0.29$ \\
\hline
\end{tabular}

Table 4 showed the range of formaldehyde content in grape collected from three different shops of three local markers. The formaldehyde content of grape found is $4.92 \pm 0.23$ as maximum in Mohammadpur bazaar whereas the minimum content of formalin found as $0.93 \pm 0.03$ in Gulistan bazaar. 18 samples of grape are found as above the acceptable limit for human consumption.

\section{Distribution of Local Market of Formalin Content in Fruits \\ - Mango Apple $\square$ Grape}

8

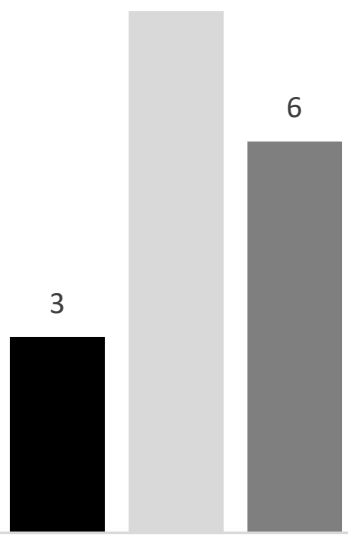

Mohammadpur Bazaar

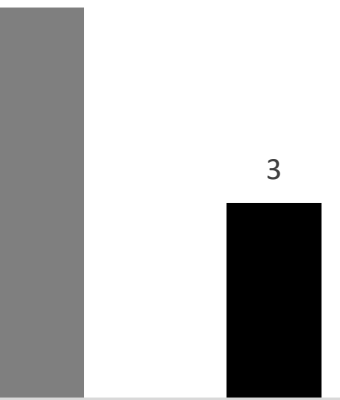

Mohakhali Bazaar
8

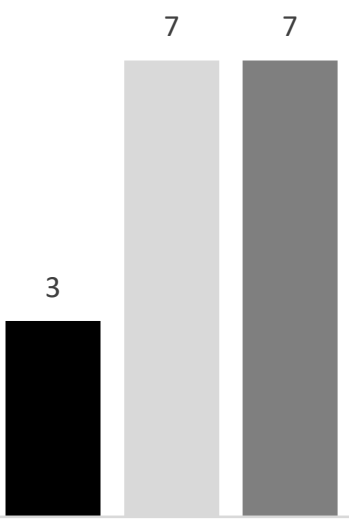

0

Gulistan Bazaar

Figure 1: Distribution of local markets in formaldehyde content in acceptable limit 
The three local markets such as Mohammadpur Bazaar, Mohakhali Bazaar and Gulistan Bazaar are known as the most popular market in Dhaka city. A lot of fruit vendors available here and there in the city those were selected for the sample collection. Among the markets 3 sample of mango, 8 sample of apple and 6 sample of grape in Mohammadpur Bazaar; 3 sample of mango, 7 sample of apple and 7 sample of grape in Mohakhali Bazaar and 8 sample of apple and 5 sample of grape in Gulistan Bazaar are found unacceptable for human consumption according the permissible limit.

\section{Conclusion}

The result of the study revealed that the content of formaldehyde in three different fruits in the local market of Dhaka city of Bangladesh. Fruits content formaldehyde naturally but Formaldehyde is used as an antibacterial agent in processing of foodstuffs. The causes of formalin contamination is different fruits are due to lack of postharvest technology, inadequate cold storage facilities, discontented transport facilities, lack of awareness, uncontrolled use of harmful chemicals etc. It was observed that control of three fruits has naturally occurring formaldehyde. Level of formaldehyde in Apple and Grape were found in this work were above the limits published by the World Health Organization and European Food safety Authority. According to the World Health Organization (WHO), in apple formalin contain 6.3 to $22.3 \mathrm{mg} / \mathrm{kg}$, in grape $22.4 \mathrm{mg} / \mathrm{kg}$ and in mango 1 to $60 \mathrm{ppm}$ naturally. According to the established maximum residual level (MRL) of formalin in fruits, Apple is more contaminated by formalin than Mango and Grape. On the other hand all the apple and grape are imported from other countries and the imported fruits are more contaminated than the seasonal fruits such as mango.

\section{Acknowledgements}

The authors are thankful to Dr. Md Shahinul Haque Khan, Associate Professor, Department of Chemistry, Bangladesh University of Health Science for the wishful support and encouragement during this experiment.

\section{References}

Adedotun A. Adenusi. Wunmi A. Abimbola and Thomas O.S. Adewoga (2015). Human intestinal helminth contamination in pre-washed, fresh vegetables for sale in major markets in Ogun State, southwest Nigeria, Food Control, 50:843-849.

Aminah, A., Zailina, H., \& Fatimah, A. B. (2013). Health risk assessment of adults consuming commercial fish contaminated with formaldehyde. Food and Public Health, 3(1):52-58.

European Food Safety Authority (EFSA) (2014). Endogenous formaldehyde turnover in humans compared with exogenous contribution from food sources. EFSA Journal, 12(2):3550.

Hossain MM. (2011). Consumption in Rural Bangladesh: Households, Lifestyles, and Identities. Academic Dissertation presented to Consumer Economics Unit, Department of Economics and Management, University of Helsinki, Finland.

Hossain MS, Rahman MA, Sharkar TK, Shahjalal HM. (2008).Formaldehyde content in the Rui Fish (Labeorohita) in Bangladesh and effect of formaldehyde on lipid per oxidation in rat liver and intestinal tissues. J. Med. Sci., 8(4): 405-409.

Jianrong, L., Junli, Z., \&Lifang, Y. (2007).Determination of formaldehyde in squid by high-performance liquid chromatography. Asia Pacific Journal of Clinical Nutrition, 16:127-130.

Kaminski, J.,Atwal, A.S., \&Mahadevan, S.(1993). Determination of formaldehydein fresh and retail milk by liquid column chromatography. Journal of AOAC International, 76(5):1010-1013.

Kamruzzaman M and Hakim M A. (2016a). Factors Associated with the Suicidal Tsunami as a Mental Illness: Findings from an Epidemiological Study. American Journal of Environment and Sustainable Development, $1(1): 1-5$

Kamruzzaman M and Hakim M A. (2016b) Prostitution Going Spiral: The Myth of Commercial Child Sex. International Journal of Biomedical and Clinical Sciences, 1(1): 1-6.

Md. FaruqueMiah, TawhidaKhanom Tania, NajmunNahar Begum and ZobadaKanak Khan (2013). Effects of Formalin Contaminated Food on Reproductive Cycle and Lifespan of Drosophila Melanogaster. Advances in Zoology and .Botany, 3: 6570.

P. F. Ross, H. Draayer, O. Hoh. (2002). An international collaborative study on a method for determination of formaldehyde in veterinary vaccines. Biologicals, 30: 37-41.

Smedje, G., D. Norback.."Incidence of asthma diagnosis and self-reported allergy in relation to the school environment--a four-year follow-up study in schoolchildren."Int.J.Tuberc.Lung Dis. 5(11):1059-1066, 2011.

Tai-Sheng Y., Tzu-Chun,L., Ching-Chuan C. and Hwui-Mei W.(2013). Analysis of free and bound formaldehyde in squid and squid products by gas chromatography- mass spectrometry. Journal of Food and Drug analysis, 21:190-197.

United States Environmental Protection Agency (USEPA) (2010). Toxicological review of formaldehydeinhalation assessment. Washington, DC: USEPA. EPA/635/R-10/ 002A. URL: http://cfpub.epa. 
Gov/ncea/iris drafts/recordisplay.dfm?deid= 223614 .

Wantke F, Focke M, Hemmer W, et al. Exposure to formaldehyde and phenol during an anatomy dissecting course: sensitizing potency of formaldehyde in medical students. Allergy, 55:84-7, 2000.

World Health Organization. Environmental health criteria (1989).Formaldehyde. Geneva, Switzerland: WHO. Available at: http://www.inchem.org/documents/ehc/ehc/ehc8 